\title{
Solidarity Activism in Germany: What Explains Different Types and Levels of Engagement?
}

Johannes Kiess, Christian Lahusen, and Ulrike Zschache

\section{INTRODUCTION}

During the summer of 2015, an unprecedented wave of solidarity with incoming refugees from Syria and other countries of the Middle East, Africa and Asia swept through Germany. Innumerable initiatives and individual citizens committed to what was called the new German "welcoming culture". These initiatives not only engaged in the provision of immediate help (e.g., clothing, food, shelter, language courses and assistance with German administration) but also rallied in support of migrant and refugee rights. The inability of German authorities to handle the inflow of migrants and the growing mobilization of populist, right-wing and xenophobic groups, dampened the "welcoming culture" considerably and boosted conflicts on the correct policies for the German administration to pursue. As a consequence, solidarity became a contested issue. While some rallied for solidarity with all people in need of help-refugees included-and insisted that "we can do this" (Schiffauer et al. 2017), oth-

J. Kiess $(\bowtie) \bullet$ C. Lahusen $\bullet$ U. Zschache

Department of Social Sciences, University of Siegen, Siegen, Germany

(C) The Author(s) 2018

C. Lahusen, M. Grasso (eds.), Solidarity in Europe,

Palgrave Studies in European Political Sociology,

https://doi.org/10.1007/978-3-319-73335-7_3 
ers proclaimed the need to refrain from unlimited assistance and instead opt for the exclusive support of Germans, fearing that the multiple crises in the world would eventually hit Germany as well. Consequently, it seems as though solidarity has become a contentious field that separates people with different cultural orientations, political beliefs and social standing.

Given this background, it is important to map the field of solidarity within the German population. For this purpose, we will make use of the survey data provided by the "European paths to transnational solidarity at times of crisis: Conditions, forms, role models and policy responses (TransSOL)" project. Our aim is to answer the following series of questions. How diffused is the disposition to engage for solidarity within the German population, and are there differences in the degree of reported activities when distinguishing between various target groups? What can we say about those people who report being committed to solidarity activities when compared to those indicating they abstain? Are there specific social traits (e.g., socio-demographic characteristics, social standing, attitudinal dispositions or cultural values) that distinguish one group from the other? In order to answer these questions, the chapter will proceed as follows. Firstly, we will briefly introduce previous research on solidarity dispositions and activities in order to identify the core social traits that play a role in distinguishing the "active" from the "inactive". Secondly, we will describe the frequencies of different solidarity actions in regard to various target groups: on the one hand, with reference to spatial entities (people in the respondents' own country, within the EU and outside the EU), and on the other hand, in regard to three issue field specific target groups, namely, refugees, the unemployed and people with disabilities. Thirdly, we will conduct a series of multinominal regression analyses in order to identify the social profile of the "active" and thus to validate the various research assumptions about relevant social, economic or cultural differences between the groups acting and not acting on behalf of others. In this context, we will also deal with issue field specific motivations and beliefs that might explain why people decide to engage for specific target groups. Finally, we will summarize and briefly discuss the core findings of this chapter.

\section{Theories of Solidarity Activism}

Our analysis of solidarity in Germany requires a brief summary of previous research findings in order to identify those potential traits that might enable us to distinguish active from the inactive citizens, and thus to 
identify those social traits that might increase the probability of being engaged in solidarity activities. Relevant insights come from different strands of research because social solidarity touches the study of public support for redistribution and redistributive policies, of social capital and social movements, among others. Many of these studies tend to paint a similar picture of solidarity-related activities. First of all, we know from research on political behaviour and social movements that resources, skills and opportunities do matter (Brady et al. 1995; Verba et al. 1978; Jenkins 1983), which means that the socio-demographic characteristics of citizens determine to a certain extent their readiness to engage in political and social activities. Age, for instance, matters in terms of biographical availability (Beyerlein and Bergstrand 2013), since people might reduce their social and political activities because of personal constraints, for example, due to marriage or family responsibilities. The unequal access to resources and skills (e.g., income and education) impinges on levels of political and civic engagement as well, meaning that socially excluded people might be more affected by a lower degree of social and political engagement (Verba et al. 1978; Kronauer 1998). Finally, we need to look at the effect of migration, because research has shown that migrants might be involved in (cross-national) forms of solidarity in support of ethnic diasporas or communities (Morokvasic 1999; Schulze 2004).

Building on these observations, we might expect-secondly—that social class might be a relevant factor as well (Cainzos and Voces 2010). Following the findings of other studies, we expect the middle classes to be overrepresented in political and social activism, as this reflects their preferences, civic norms and their economic, cultural and social capital (Kriesi 1989; Eder 1993). At the same time, however, we know from studies on the support of redistributional policies that vulnerability and deprivation do impinge positively on solidarity disposition (Iversen and Soskice 2001; Rehm 2009), at least in regard to target groups exposed to similar risks of social exclusion and degradation. In this regard, we thus need to measure the potential effect of several variables that are related to social class and social exclusion. For this purpose, we will also look at subjective class affiliation and feelings of deprivation. Beyond that, we will look at the living situation and international exposure (housing situation and number of friends from different countries) in order to assess whether social isolation and contact with individuals outside one's social group might be related to social solidarity.

A third set of expectations is related to ideational factors, such as feelings of collective identity, political beliefs, religiosity and trust. The social 
movement literature holds it that cultural and moral resources, in addition to material, organizational and human resources, are important for explaining the successful emergence of collective action (Edwards and McCarthy 2004). In the first instance, we know that individual dispositions to engage in solidarity activities and support redistributive policies are closely related to religiosity, given that religion generally supports the idea of helping others (Stegmueller et al. 2012; Lichterman 2015). Moreover, we assume that solidarity is determined by collective identities, in the sense that feelings of belongingness to certain collectivities might increase the readiness to support members of these (imagined) communities. National identities should thus be interrelated to forms of solidarity with fellow citizens, European identification with solidarity activities in support of people living in other European member states (Bauböck 2017). Additionally, we expect that political preferences and orientations make a difference in regard to solidarity. In general terms, solidarity might be more diffused among respondents with leftist political orientations and preferences for multiculturalism, while xenophobic, right-wing and populist dispositions might be more probable among the inactive, as corroborated in regard to public policies (Likki and Staerklé 2014). However, the latter ideological preferences might be linked to certain forms of groupbound solidarity, for example, within nations or specific target groups (e.g., the unemployed). Finally, solidarity could also be more common among people with higher levels of interpersonal trust, when considering research on social capital that highlights the importance of trust, membership and active participation in civic associations and groups (Putnam et al. 2003; van Oorschot et al. 2006).

A final set of factors to be taken into consideration is related more strictly to specific issue fields. This last group follows the basic idea that solidarity is not necessarily a universal disposition of support related to anybody, that is, to all human beings. Possibly, solidarity is always groupbound, meaning that citizens tend to centre their engagement to certain groups to which they feel particularly attached. This argument puts an emphasis on the fact that solidarity needs to be activated (against potentially detrimental factors such as lack of resources, social exclusion or apathy) and that this is more probable in regard to people to whom one feels personally attached. Feelings of social proximity between oneself and the target groups seem to play a role here (van Oorschot 2006; Stegmueller et al. 2012), which means that empathy with significant others is thus an important "opener" that helps to mobilize support. At the same time, 
however, this means that solidarity might be-per se-limited to specific groups, a predisposition that has been called philanthropic particularism (Komter 2005). Hence, we expect feelings of attachment towards specific groups and the belief that a fair society implies the inclusion of and assistance to specific groups to increase solidarity activity towards them.

\section{Measurement}

Our analysis draws on an original dataset of 2064 respondents (aged 18+) in Germany matched for age, gender, region and education level quotas to national population statistics. Weights were applied in all descriptive analyses and all models control for age, gender and education. Data retrieval was conducted as part of the Horizon 2020 project TransSOL using CAWI method (computer-assisted web interviewing) and took place between December 2016 and January 2017. ${ }^{1}$ The dependent variables intend to measure reported solidarity activity on behalf of different groups and on different levels. The questionnaire specifies for all three groups ("Have you ever done one of the following in order to support the rights of...”). We report all variables used for modelling, including recoding procedures, in the Appendix.

\section{FINDINGS}

In this section we present findings on solidarity actions in Germany across three levels (national, EU, outside EU) as well as three fields of solidarity, namely, the support of refugees and asylum seekers, of the unemployed and people with disabilities. We begin with descriptive findings along the six dimensions. In the second part, we present findings of multinominal regression analyses identifying socio-structural and ideational factors that influence the probability of people choosing to engage in solidarity actions. In a third subsection, we turn to group specific motifs and beliefs to better explain engagement in solidarity activities.

\section{Frequencies of Solidarity Action: Descriptive Results}

Table 3.1 shows two patterns: first, solidarity depends on proximity since engagement is more frequent in support for people and their rights in the respondent's own country than abroad and support for people outside the $\mathrm{EU}$ is also quite frequent, but focused on activities like donating money 
Table 3.1 Frequencies of engagement over levels and fields of solidarity (in \%)

\begin{tabular}{|c|c|c|c|c|c|c|c|c|}
\hline & $\begin{array}{c}\text { Attended } \\
\text { march }\end{array}$ & $\begin{array}{l}\text { Donate } \\
\text { money }\end{array}$ & $\begin{array}{c}\text { Donate } \\
\text { time }\end{array}$ & $\begin{array}{c}\text { Buycott/ } \\
\text { boycott }\end{array}$ & $\begin{array}{l}\text { Passive } \\
\text { member }\end{array}$ & $\begin{array}{l}\text { Active } \\
\text { member }\end{array}$ & None & $R^{2}$ \\
\hline $\begin{array}{l}\text { Support of rights / } \\
\text { people in own } \\
\text { country }\end{array}$ & 12.7 & 24.0 & 19.0 & 20.7 & 5.5 & 10.2 & 49.0 & 0.58 \\
\hline $\begin{array}{l}\text { Support of rights / } \\
\text { people in other } \\
\text { EU country }\end{array}$ & 6.5 & 13.4 & 8.8 & 15.0 & 3.4 & 4.7 & 68.6 & 0.59 \\
\hline $\begin{array}{l}\text { Support of rights / } \\
\text { people in country } \\
\text { outside EU }\end{array}$ & 5.8 & 20.8 & 9.3 & 19.0 & 3.0 & 4.1 & 60.0 & 0.50 \\
\hline $\begin{array}{l}\text { Support rights of } \\
\text { asylum seekers/ } \\
\text { refugees }\end{array}$ & 5.3 & 15.2 & 14.1 & 9.2 & 2.8 & 6.3 & 65.9 & 0.50 \\
\hline $\begin{array}{l}\text { Support rights of } \\
\text { unemployed }\end{array}$ & 4.7 & 8.2 & 10.2 & 9.6 & 2.6 & 4.9 & 73.0 & 0.49 \\
\hline $\begin{array}{l}\text { Support disability } \\
\text { rights }\end{array}$ & 3.9 & 26.5 & 19.0 & 18.6 & 5.4 & 7.5 & 48.4 & 0.44 \\
\hline$R^{2}$ & 0.68 & 0.51 & 0.74 & 0.73 & 0.59 & 0.67 & 0.81 & \\
\hline
\end{tabular}

and buycotting/boycotting products. Moreover, our data allows us to distinguish between the support for our three main target groups: asylum seekers/refugees, unemployed and disabled people. Here we observe, overall, the highest frequencies in the field of disability rights. Support of refugees is more limited but still exceeds support of the unemployed. This shows that solidarity is not a generalized disposition or practice but that it is linked to specific issues and target groups drawing a pattern of affinity: in spatial terms people in one's own country receive the most support, as do disabled if we compare between issue fields. In comparison, people in other EU countries and the unemployed receive the least support. In this respect, the findings provide a first hint to the fact that solidarity is shaped by feelings of attachment to particular groups. We will return to this issue in the third part of our analysis.

Beyond descriptive frequencies, we were interested in the connections between different solidarity actions people engage in and also similarities across issue fields (i.e., solidarity towards the unemployed, disabled and refugees). Some types of action may be considered more demanding, for example, in terms of resources, than others. Likewise, some fields may be more prone to attract civil engagement because of current media attention 
or differently perceived proximity to the target group. Moreover, activists who join certain activities may do so across levels (national, European and outside Europe) and across issue fields.

In a next explorative step and following these considerations, we conducted principal factor analyses for both the issue fields and levels of solidarity (do people in one field engage in multiple activities?) and the activities across fields (do people choosing one activity in one field also chose this in another field?). In regard to the activities within levels and fields, we found-to some surprise - that at no level and in no issue field did the analysis reveal more than one factor ${ }^{2}$ : there do not seem to be different types of activists, for example, those who protest on behalf of refugees on the one hand and those who spend time and money on the other hand. In this respect, we may expect variation rather between those opting to engage and those not acting at all. Similarly to the fields of activity, we could not find any differences within action types across fields. This suggests that people who protest or spend money do so with-to this point-no relevant difference in terms of activity chosen across fields. Simple bivariate regression shows, for example, a correlation between protesting for unemployed and protesting for refugees. We may conclude that people protesting for one group are also prone to protest for another.

This does not indicate, however, that the same people are likely to engage in all different types of solidarity action and for all groups at the same time. It is more likely that actions vary enough to disguise specific patterns - other than that solidarity activities in one field and one type are likely to go together with activity in another field and commute with other activities. Moreover and as we will argue below, active people choose their field of activity based on attachment towards specific groups or issues. Before we turn to this, we want to differentiate and compare the intensity of activity in each issue field to complete this descriptive subsection.

Table 3.2 shows the intensity of engagement, thus revealing if and to what extent active persons are engaged in several forms of action. ${ }^{3}$ On first sight, the table provides a clear picture with the frequencies declining in parallel with the intensity of engagement. However, we also observe that only a very small minority engages more deeply in either field and on either level of solidarity. If we consider the threshold for engaging in one activity only as relatively low (e.g., it could be a one-time action of donating five euro to an integrative school project with no further involvement and, more importantly, no indication of repetition), the percentage of people engaging considerably in solidarity activities in the population is between 10 and $20 \%$. 
Table 3.2 Multiple forms of actions over levels and fields of solidarity (in \%)

\begin{tabular}{lccccccc}
\hline & None & $\begin{array}{c}\text { One } \\
\text { activity }\end{array}$ & $\begin{array}{c}\text { Two } \\
\text { activities }\end{array}$ & $\begin{array}{c}\text { Three } \\
\text { activities }\end{array}$ & $\begin{array}{c}\text { Four } \\
\text { activities }\end{array}$ & $\begin{array}{c}\text { Five } \\
\text { activities }\end{array}$ & $\begin{array}{c}\text { All six } \\
\text { activities }\end{array}$ \\
\hline $\begin{array}{l}\text { Support of rights/ } \\
\text { people in own }\end{array}$ & 49.0 & 28.1 & 11.9 & 6.2 & 2.7 & 1.8 & 0.3 \\
$\begin{array}{l}\text { country } \\
\text { Support of rights/ } \\
\text { people in other EU }\end{array}$ & 68.6 & 19.5 & 6.4 & 3.7 & 1.1 & 0.5 & 0.2 \\
$\begin{array}{l}\text { country } \\
\text { Support of rights/ } \\
\text { people in country } \\
\text { outside EU }\end{array}$ & 60.0 & 25.5 & 9.4 & 3.2 & 1.3 & 0.4 & 0.2 \\
$\begin{array}{l}\text { Support rights of } \\
\text { asylum seekers }\end{array}$ & 65.9 & 21.5 & 8.5 & 2.7 & 0.9 & 0.5 & 0.1 \\
$\begin{array}{l}\text { refugees } \\
\text { Support rights of }\end{array}$ & 73.0 & 18.1 & 6.0 & 1.9 & 0.7 & 0.2 & 0.1 \\
$\begin{array}{l}\text { unemployed } \\
\text { Support disability } \\
\text { rights }\end{array}$ & 48.4 & 32.9 & 11.8 & 4.3 & 1.8 & 0.8 & 0.1 \\
\hline
\end{tabular}

These findings led us to choose the summary frequencies in the different solidarity fields as our dependent variable for further analysis" ${ }^{4}$ We decided to differentiate between three groups: those not engaging at all, the one-action activists and multiply engaged respondents. Even though different action forms were only moderately interrelated in each of the fields and on each of the levels (with Cronbach's alpha's at only around 0.5 , see last column of Table 3.1 ), the usage of summary variables for each issue field and distinguishing along intensity, while making sure through factor analyses that there are not different dimensions involved, seems to be an acceptable compromise.

\section{Comparing the Active and the Inactive: Socio-structural and Ideational Factors}

Following the findings of our descriptive analysis, we opted for multinominal regression models. This allows us to compare those who do not engage with the "one-action activists", as well as those who engage in different activities. This was done without assuming linearity of our dependent variable, which might not hold considering the small Cronbach's alpha. We will present different models, including different sets of vari- 
Table 3.3 Multinominal regression models la-lf (socio-economic variables)

\begin{tabular}{|c|c|c|c|c|c|c|c|}
\hline & & Germany & Other EU & Global & Refugees & Unemplo & Dissabil \\
\hline \multirow{6}{*}{$\begin{array}{l}\text { One } \\
\text { action }\end{array}$} & Age & $-0.169^{* *}$ & $-0.217^{* *}$ & $-0.164^{* *}$ & $-0.236^{* *}$ & $-0.224^{* *}$ & 0.039 \\
\hline & Income & $0.121^{*}$ & $0.139^{*}$ & $0.184^{* *}$ & 0.122 * & 0.114 & 0.189 ** \\
\hline & Education & 0.109 & 0.131 * & 0.214 * * & 0.092 & 0.080 & 0.037 \\
\hline & Male & -0.005 & 0.137 & $-0.228^{*}$ & -0.004 & 0.150 & -0.001 \\
\hline & Migrant & 0.008 & 0.213 & 0.160 & 0.088 & 0.151 & 0.123 \\
\hline & _Cons & -0.510 ** & $-1.329 * *$ & $-0.695^{* *}$ & -1.084 ** & $-1.444^{* *}$ & -0.369 ** \\
\hline \multirow{6}{*}{$\begin{array}{l}\text { Multiple } \\
\text { actions }\end{array}$} & Age & -0.029 & -0.127 & $-0.179^{*}$ & -0.103 & -0.006 & $0.166^{*}$ \\
\hline & Income & 0.115 & $0.181^{*}$ & 0.242 ** & 0.238 ** & 0.028 & 0.110 \\
\hline & Education & 0.289 ** & 0.190 * & $0.393^{* *}$ & 0.213 ** & 0.174 * & 0.286 ** \\
\hline & Male & -0.067 & 0.212 & $-0.330^{*}$ & -0.165 & $0.333^{*}$ & -0.014 \\
\hline & Migrant & 0.198 & $0.388^{*}$ & $0.537^{* *}$ & 0.500 ** & $0.556^{* *}$ & 0.277 \\
\hline & _Cons & $-0.753^{* *}$ & $-1.926^{* *}$ & $-1.358^{* *}$ & $-1.701 * *$ & $-2.328 * *$ & $-0.975^{* *}$ \\
\hline \multicolumn{2}{|l|}{$N$} & 1800 & 1800 & 1800 & 1800 & 1800 & 1800 \\
\hline \multicolumn{2}{|c|}{ Pseudo- $R^{2}$} & 0.0117 & 0.0151 & 0.0263 & 0.0159 & 0.0130 & 0.0122 \\
\hline
\end{tabular}

${ }^{*} p<0.05,{ }^{* *} p<0.01$

ables, and will focus in this subsection on the comparison of the different fields and levels of solidarity. Thus, we calculated each of the models (1-3) separately for the different fields and levels of solidarity (indicated by $\mathrm{a}-\mathrm{f}$ ).

In the first step, we only included socio-economic variables (as well as the country weight). While increasing age may increment opportunities to engage in solidarity activities, income and education can be interpreted as variables indicating resources. Thus higher income and higher education may increase the probability of engagement as well. We include gender as a control variable. Migrant background sometimes comes with additional social capital but also vulnerability. Accordingly, we may expect a positive influence on solidarity activities. As Table 3.3 shows, we find a lot of significant correlations, but there are some differences we will need to point out. First, if we compare those engaging in one activity with those not engaging, age is significant across all fields and levels, excluding the support of disability rights. Moreover, the effect suggests that the younger people are, the more likely they are to engage in one action relative to none. If we compare with those engaging in at least two activities, however, the effect is only significant for engagement for people outside of Europe. In this case, the effect for solidarity with people with disabilities is reversed: those engaging for the rights of this group in various forms are more likely to be older. Income is positively correlated with engagement 
for both groups, the "one-action" activists and the "multiply active". However, the effect is not significant for both groups concerning the rights of the unemployed. Moreover, education is for "one-action" activists only relevant if they engage on the European or global level. But for the "multiply active", we find that higher education leads to more engagement on all fields and issues relative to non-actives. Gender has a very limited impact overall. Migrant background, finally, has no impact on single-activity engagement, but it increases chances to be multiply active on the European and global level, on behalf of refugees and also on behalf of the unemployed. To summarize, our findings suggest in line with the literature (Brady et al. 1995; Verba et al. 1978; Jenkins 1983) that resources play an important role and the young are more frequently engaged in one action relative to none, but we must also emphasize that the explained variance through these variables is very low. This means that other factors must play a role.

In a second series of calculations, we added further and also subjective socio-structural variables to our model (see Table 3.4). Age remains significant for the one-action activists (with the exceptions of global solidarity and disability rights), and education underlines its importance for all issue fields and solidarity levels. Self-placement in a lower social class reduces only solidarity on the European level for one-action activists - which is in line with current observations in the EU (e.g., Brexit). However, income loses its limited effect almost entirely, and there are no clear effects across fields. Material resources do not seem to play a dominant role, and this observation seems plausible, because the type of activities we asked our respondents to comment on are not particularly costly.

If we turn to the perception of (collective) resources, this changes only on first sight: for one-action activists, positive perception of living conditions in Germany seems to mobilize for solidarity in and beyond Europe as well as for the unemployed and people with disabilities, relative to inactives. However, this result does not hold for our second group, those who engage in multiple activities, relative to inactives. Here, having friends from other countries spurs solidarity towards refugees, disabled people but also people within the country in general. The experience of relative deprivation increases the chances of multiple activism on behalf of the unemployed (and vice versa) but has no effect on other fields of solidarity. Overall, we find that being younger and having German residence generally has a positive effect on having participated at least once relative to never. Education is the most important factor for 
Table 3.4 Multinominal regression models $2 \mathrm{a}-2 \mathrm{f}-$-socio-structural determinants

\begin{tabular}{|c|c|c|c|c|c|c|c|}
\hline & & Germany & Other EU & Global & Refugees & Unemplo & Dissabil \\
\hline \multirow{12}{*}{$\begin{array}{l}\text { One } \\
\text { action }\end{array}$} & Age & -0.124 & -0.182 ** & -0.101 & $-0.181 * *$ & $-0.237^{* *}$ & 0.013 \\
\hline & Income & 0.047 & 0.002 & 0.158 & -0.054 & 0.111 & 0.084 \\
\hline & Education & 0.064 & 0.126 & $0.163^{*}$ & 0.086 & 0.057 & 0.030 \\
\hline & Male & -0.005 & 0.084 & -0.199 & 0.037 & 0.199 & -0.053 \\
\hline & Migrant & -0.034 & 0.259 & 0.169 & 0.115 & 0.086 & 0.008 \\
\hline & Socialclass & -0.004 & -0.229 ** & -0.025 & -0.099 & 0.046 & -0.001 \\
\hline & Reldep & 0.012 & -0.140 & 0.031 & 0.148 & -0.111 & 0.028 \\
\hline & $\begin{array}{l}\text { Living in } \\
\text { Germany }\end{array}$ & 0.094 & 0.230 ** & 0.141 * & $0.137^{*}$ & $0.253^{* *}$ & 0.164 ** \\
\hline & Friendsdiff & -0.089 & -0.060 & 0.000 & 0.002 & -0.116 & 0.058 \\
\hline & Live alone & -0.052 & -0.062 & 0.056 & -0.192 & -0.325 & -0.190 \\
\hline & East & -0.222 & 0.073 & -0.041 & -0.209 & 0.159 & 0.109 \\
\hline & _Cons & -0.359 ** & $-1.239 * *$ & $-0.634^{* *}$ & $-0.967 * *$ & $-1.387 * *$ & -0.197 \\
\hline \multirow{12}{*}{$\begin{array}{l}\text { Multiple } \\
\text { actions }\end{array}$} & Age & -0.018 & -0.133 & -0.125 & -0.090 & -0.067 & 0.140 \\
\hline & Income & 0.028 & 0.068 & 0.208 & 0.126 & 0.010 & -0.152 \\
\hline & Education & $0.275^{* *}$ & 0.200 * & 0.408 ** & $0.209^{* *}$ & 0.211 * & 0.317 * * \\
\hline & Male & -0.121 & 0.101 & $-0.403^{* *}$ & -0.218 & 0.258 & -0.116 \\
\hline & Migrant & -0.012 & 0.279 & 0.467 * & 0.349 & $0.475^{*}$ & 0.033 \\
\hline & Socialclass & -0.082 & -0.139 & -0.048 & -0.120 & -0.093 & $-0.175^{*}$ \\
\hline & Reldep & -0.026 & -0.084 & 0.004 & 0.029 & -0.322 ** & -0.047 \\
\hline & $\begin{array}{l}\text { Living in } \\
\text { Germany }\end{array}$ & -0.002 & 0.076 & 0.140 & 0.077 & 0.094 & 0.091 \\
\hline & Friendsdiff & $0.145^{*}$ & 0.091 & 0.125 & $0.178 * *$ & -0.055 & 0.138 * \\
\hline & Live alone & 0.140 & 0.075 & 0.336 & $0.403^{*}$ & -0.203 & $-0.380^{*}$ \\
\hline & East & $-0.413^{*}$ & -0.037 & -0.296 & $-0.579^{*}$ & -0.494 & -0.439 * \\
\hline & _Cons & $-0.548^{* *}$ & $-1.768^{* *}$ & $-1.273^{* *}$ & $-1.543^{* *}$ & $-2.046^{* *}$ & $-0.574^{* *}$ \\
\hline \multicolumn{2}{|l|}{$N$} & 1500 & 1500 & 1500 & 1500 & 1500 & 1500 \\
\hline \multicolumn{2}{|c|}{ Pseudo- $R^{2}$} & 0.0153 & 0.0202 & 0.0287 & 0.0269 & 0.0279 & 0.0190 \\
\hline
\end{tabular}

${ }^{*} p<0.05,{ }^{*} p<0.01$

distinguishing between multiple activists and inactives-this confirms resource-based and civic voluntarism theories in the literature (Verba et al. 1995). Moreover, there are specific effects of other variables like social class for helping people in other EU countries, relative deprivation for helping unemployed and having friends from different countries and helping refugees.

In a third series of calculations, we included variables for cultural and ideational factors (see Table 3.5). Religiosity and social trust seem to impact solidarity activity considerably. This is in line with the literature, 
pointing to cultural and moral resources as grounds for civil society mobilization. In turn, the already limited effects of socio-structural determinants are weakened. For example, the living conditions in Germany are now only a significant factor for solidarity with unemployed and European solidarity, having friends from different countries is not significant anymore and so on. Only the effect of relative deprivation ${ }^{5}$ on

Table 3.5 Multinominal regression models $3 \mathrm{a}-3 \mathrm{f}-$ cultural-ideational determinants

\begin{tabular}{|c|c|c|c|c|c|c|c|}
\hline & & Germany & Other EU & Global & Refugees & Unemplo & Dissabil \\
\hline One & Age & -0.128 & $-0.168^{*}$ & -0.134 & $-0.186^{*}$ & $-0.259^{* *}$ & -0.030 \\
\hline \multirow[t]{25}{*}{ action } & Income & 0.053 & 0.022 & $0.217^{*}$ & -0.000 & 0.048 & 0.115 \\
\hline & Education & 0.004 & 0.114 & 0.127 & 0.034 & 0.002 & -0.025 \\
\hline & Male & 0.161 & 0.085 & -0.236 & 0.030 & 0.176 & -0.035 \\
\hline & Migrant & -0.056 & 0.256 & 0.100 & 0.044 & -0.070 & -0.154 \\
\hline & Socialclass & -0.088 & $-0.235^{*}$ & -0.021 & -0.108 & -0.046 & 0.007 \\
\hline & Reldep & -0.144 & $-0.237^{\star}$ & -0.132 & -0.114 & $-0.248^{*}$ & -0.134 \\
\hline & $\begin{array}{l}\text { Living in } \\
\mathrm{DE}\end{array}$ & 0.026 & $0.225^{* *}$ & 0.143 & 0.065 & $0.184^{*}$ & 0.054 \\
\hline & Friendsdiff & -0.069 & -0.170 & 0.036 & -0.012 & -0.089 & -0.003 \\
\hline & Live alone & -0.018 & -0.033 & 0.032 & -0.210 & -0.415 & -0.186 \\
\hline & East & -0.153 & 0.110 & -0.135 & -0.100 & 0.178 & 0.099 \\
\hline & $\begin{array}{l}\text { Attached } \\
\text { DE }\end{array}$ & -0.143 & $-0.229^{*}$ & -0.116 & -0.185 & -0.147 & 0.043 \\
\hline & $\begin{array}{l}\text { Attached } \\
\text { city }\end{array}$ & 0.156 & 0.025 & 0.112 & -0.073 & 0.041 & -0.209 \\
\hline & $\begin{array}{l}\text { Attached } \\
\text { reg }\end{array}$ & 0.074 & 0.170 & -0.044 & 0.056 & 0.140 & 0.175 \\
\hline & $\begin{array}{l}\text { Attached } \\
\text { EU }\end{array}$ & 0.085 & 0.269 * * & $0.237^{*}$ & $0.376^{* *}$ & $0.284^{* *}$ & 0.157 \\
\hline & $\begin{array}{l}\text { Attached } \\
\text { hu }\end{array}$ & 0.081 & 0.015 & 0.006 & -0.137 & -0.047 & 0.150 \\
\hline & Social trust & 0.196 * & 0.232 ** & 0.217 ** & 0.261 ** & $0.304 * *$ & $0.223^{* *}$ \\
\hline & Religiosity & 0.199 ** & 0.300 ** & 0.117 & $0.265^{* *}$ & $0.170^{*}$ & 0.172 * \\
\hline & Identity & -0.017 & -0.030 & 0.092 & 0.026 & 0.035 & 0.079 \\
\hline & Left self & -0.091 & -0.094 & -0.145 & -0.084 & -0.158 & 0.041 \\
\hline & Demsat & 0.011 & -0.099 & -0.056 & -0.017 & -0.080 & -0.012 \\
\hline & Multicult & 0.104 & 0.032 & -0.055 & $0.377^{* *}$ & -0.150 & 0.118 \\
\hline & Populism & 0.041 & -0.022 & 0.070 & 0.097 & $0.293^{* *}$ & $0.177^{\star}$ \\
\hline & Xeno_econ & 0.039 & 0.095 & 0.040 & 0.057 & 0.066 & 0.016 \\
\hline & Xeno_cult & 0.044 & -0.063 & $0.243^{*}$ & $0.316^{*}$ & 0.172 & -0.002 \\
\hline & _Cons & $-1.624^{* *}$ & -2.680 ** & $-1.399 * *$ & $-1.565^{* *}$ & $-2.579 * *$ & -0.864 \\
\hline
\end{tabular}


Table 3.5 (continued)

\begin{tabular}{|c|c|c|c|c|c|c|c|}
\hline & & Germany & Other EU & Global & Refugees & Unemplo & Dissabil \\
\hline Multiple & Age & -0.080 & -0.165 & -0.165 & -0.118 & -0.128 & 0.085 \\
\hline \multirow[t]{25}{*}{ actions } & Income & 0.118 & 0.157 & 0.334 ** & 0.359 ** & 0.052 & -0.030 \\
\hline & Education & $0.193^{*}$ & 0.119 & $0.313^{* *}$ & 0.129 & 0.184 & 0.258 * * \\
\hline & Male & 0.036 & 0.183 & $-0.413^{*}$ & -0.139 & 0.312 & -0.030 \\
\hline & Migrant & -0.122 & 0.121 & 0.206 & 0.161 & 0.244 & -0.237 \\
\hline & Socialclass & -0.068 & -0.091 & 0.056 & -0.054 & -0.113 & -0.160 \\
\hline & Reldep & $-0.209^{*}$ & $-0.365^{* *}$ & -0.164 & $-0.259^{*}$ & $-0.457^{* *}$ & -0.173 \\
\hline & $\begin{array}{l}\text { Living in } \\
\mathrm{DE}\end{array}$ & -0.040 & 0.052 & 0.105 & 0.010 & 0.017 & -0.003 \\
\hline & Friendsdiff & 0.113 & 0.029 & $0.184^{*}$ & 0.162 & -0.041 & 0.101 \\
\hline & Live alone & 0.169 & 0.040 & 0.161 & 0.365 & -0.146 & -0.393 \\
\hline & East & -0.272 & 0.147 & -0.122 & -0.274 & -0.355 & -0.252 \\
\hline & $\begin{array}{l}\text { Attached } \\
\text { DE }\end{array}$ & -0.096 & -0.189 & -0.168 & $-0.253^{*}$ & -0.205 & -0.083 \\
\hline & $\begin{array}{l}\text { Attached } \\
\text { city }\end{array}$ & 0.104 & -0.149 & -0.139 & -0.058 & -0.220 & -0.058 \\
\hline & $\begin{array}{l}\text { Attached } \\
\text { reg }\end{array}$ & -0.024 & 0.120 & 0.010 & -0.018 & 0.089 & 0.008 \\
\hline & $\begin{array}{l}\text { Attached } \\
\text { EU }\end{array}$ & 0.094 & 0.071 & $0.255^{*}$ & -0.014 & 0.252 & 0.028 \\
\hline & $\begin{array}{l}\text { Attached } \\
\text { hu }\end{array}$ & 0.169 & 0.25 & 0.188 & 0.025 & 0.020 & $0.271^{*}$ \\
\hline & Social trust & $0.183^{*}$ & 0.354 ** & 0.239 * & $0.265^{*}$ & -0.013 & 0.081 \\
\hline & Religiosity & 0.348 ** & 0.339 ** & $0.384^{* *}$ & $0.576^{* *}$ & 0.332 * * & 0.363 * * \\
\hline & Identity & 0.050 & 0.077 & 0.048 & 0.007 & 0.168 & 0.103 \\
\hline & Right self & -0.264 ** & -0.114 & -0.103 & $-0.346^{* *}$ & -0.089 & -0.088 \\
\hline & Demsat & -0.107 & -0.066 & $-0.235^{*}$ & 0.215 & -0.057 & 0.028 \\
\hline & Multicult & -0.008 & 0.133 & 0.198 & $0.366^{*}$ & -0.046 & 0.137 \\
\hline & Populism & 0.061 & 0.049 & 0.087 & 0.127 & $0.246^{*}$ & 0.262 ** \\
\hline & Xeno_econ & 0.220 & $0.335^{*}$ & $0.353^{*}$ & 0.265 & 0.464 ** & 0.232 \\
\hline & Xeno_cul & 0.159 & 0.137 & 0.135 & $0.398^{*}$ & -0.046 & -0.019 \\
\hline & _Cons & $-1.653^{* *}$ & $-2.866^{* *}$ & $-2.149 * *$ & $-1.771 * *$ & $-2.413^{* *}$ & -1.358 * \\
\hline \multicolumn{2}{|l|}{$N$} & 1265 & 1265 & 1265 & 1265 & 1265 & 1265 \\
\hline \multicolumn{2}{|c|}{ Pseudo- $R^{2}$} & 0.0528 & 0.0789 & 0.0849 & 0.1397 & 0.0709 & 0.0548 \\
\hline
\end{tabular}

${ }^{*} p<0.05,{ }^{* *} p<0.01$

solidarity with unemployed is strengthened. If people think they are better off, they are considerably less likely to engage in multiple actions on behalf of the unemployed. But this effect, too, is not significant for oneaction activists. 


\section{Motifs and Beliefs Explaining Solidarity Actions?}

So far, there are only a few variables that seem to be relevant across dimensions. Above all, religiosity and social trust increase the likelihood of people engaging in solidarity actions but also, to some degree, higher levels of education and younger age. Beyond that, there are factors that show significance for specific dimensions, but the patterns are hard to identify. For this reason, we engage in further analyses that include variables that could be relevant per field. In particular, we will focus on issue-specific motifs and beliefs that may increase the likelihood of respondents to have been engaged in solidarity actions on behalf of refugees, unemployed, disabled people and citizens in other European countries. ${ }^{6}$ Moreover, we will now switch the mode of presentation and describe the results for the issue fields separately and with comparisons of different models per issue field in order to focus more directly on the explanatory power of individual variables. As the second to last rows of the subsequent tables show, for the following models we used only those cases in our survey that would remain in the least inclusive model (missing in individual variables lead to the exclusion of a case) in order to ensure proper comparison across the models.

Table 3.6 presents the results for solidarity actions at the European level. We included four items that asked for the motivation to grant financial help to other European countries and that aim to measure reciprocity and deservingness as determining factors for this specific type of solidarity. In other words, we wanted to test whether redistributive attitudes are connected to individual solidarity activities. Surprisingly, none of these have a significant effect on actual solidarity activities of people on the micro level. This could be explained by the fact that people actually differentiate between financial aid and redistribution on the macro level and within the EU on the one hand and solidarity actions on behalf of other people living in these other European countries on the micro level on the other hand. What seems to impact European solidarity activities is the agreement on the policy suggestion to "pool funds to help EU countries" $(M=2.82$, see Appendix). If respondents agree to this statement, they are more likely to engage. However, this effect is not significant for those acting in multiple ways if we control for all other variables introduced above. In the controlled model, the feeling that Germany benefits from its membership in the EU (68\% of our respondents believe so, see Appendix) becomes significant. In sum, solidarity actions increase only slightly if people agree on 
Table 3.6 Multinominal regression models for European level solidarity

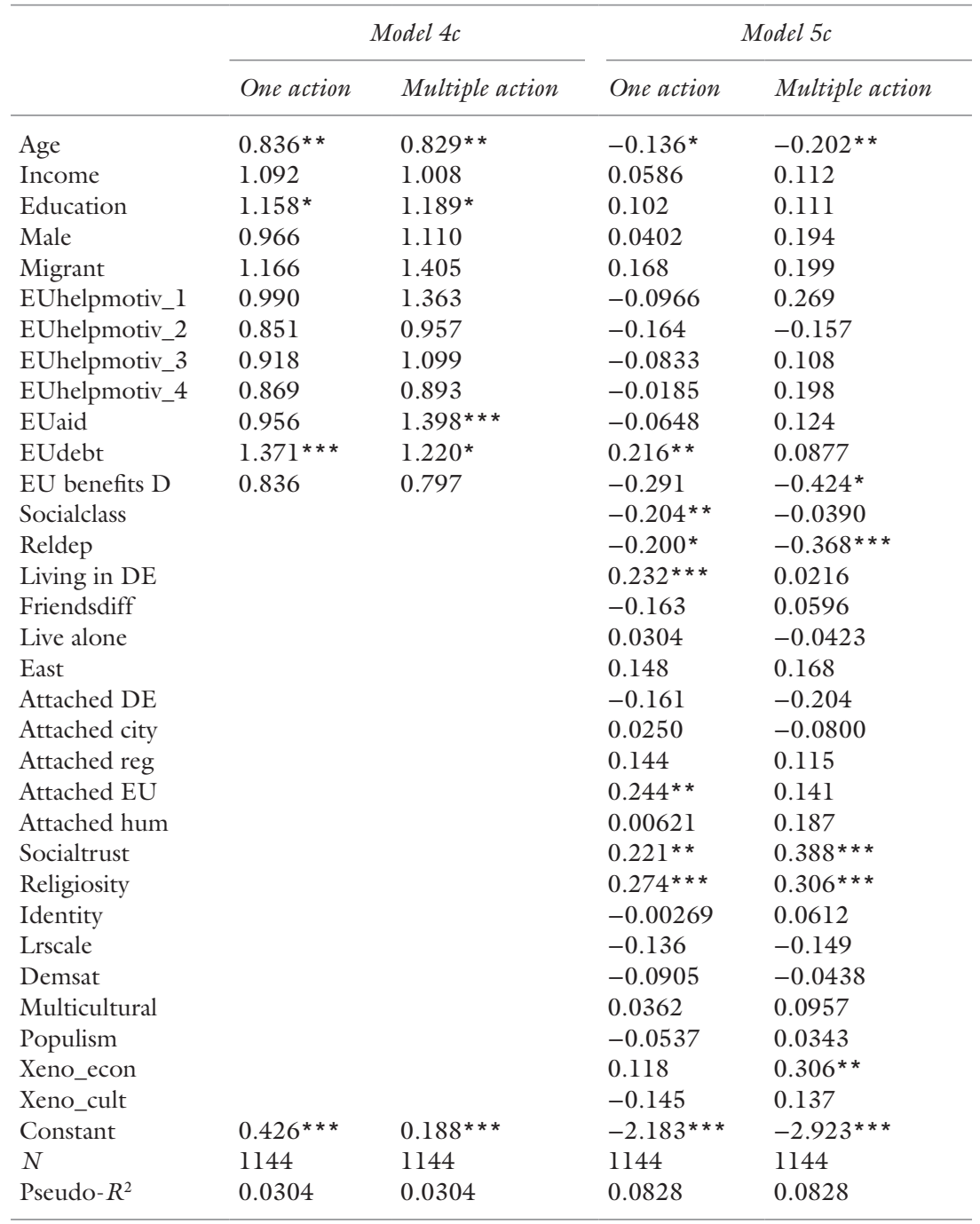

${ }^{* * *} p<0.01,{ }^{* *} p<0.05,{ }^{*} p<0.1$ 
political steps for (fiscal and financial) integration; the two topics-financial transfers on the macro level and solidarity with people on the micro level-seem to be rather disentangled from each other. This could be explained by considering the harsh preconditions that are tied to the "help" for countries in difficulties. This reading is supported by the continued importance of religiosity, social trust but also deprivation as well as the negative impact of economic xenophobia.

In recent years, the influx of large numbers of refugees has challenged German civil society. People organized to help newcomers in many places. Table 3.7 presents two models for this issue field of solidarity action. The feeling of attachment to refugees $(M=2.74$, see Appendix) seems to play an important role explaining why people are active on their behalf. Again, we can connect this with the importance of religiosity and social trust that increase solidarity activity towards refugees. Education increases only multiple engagements; income correlates positively in the full model (last column). Moreover, satisfaction with the way the government deals with refugees $(M=3.32$, see Appendix $)$ increases activity, as do beliefs that it is Germany's moral responsibility to accept refugees $(M=3.35)$ and that the government should be supporting them financially $(M=3.16)$. Interestingly xenophobia does not correlate negatively in a significant way with refugee solidarity, perhaps some people still help even though they do not see refugees as enriching the country (culturally or economically), and, vice versa, people may see immigration as a good thing but do not bother to support refugees. This is also why we see the positive correlation of populism as a sign for dissatisfaction with politics (but not with the decision to help the refugees!) rather than anti-democratic sentiment (we may speak of left-wing populism in this case). Moreover, agreeing with the European response to the refugee crisis $(M=3.80)$ is only significant in one model. Given the controversies on the European level on how to deal with refugees, it comes as no surprise that most respondents to our survey were dissatisfied (on a scale from 0 to 10). In the case of solidarity activities supporting refugees, we can conclude to see a clearer picture of why people engage. This is probably due to the fact of the heightened attention the topic had in the months before the survey was conducted.

Table 3.8 presents the results of our regressions with solidarity towards unemployed people as the dependent variable. Again, we seem to get a much better picture if we include variables measuring motivations and 
Table 3.7 Multinominal regression models for solidarity with refugees

\begin{tabular}{|c|c|c|c|c|}
\hline & \multicolumn{2}{|c|}{ Model $4 d$} & \multicolumn{2}{|c|}{ Model $5 d$} \\
\hline & One action & Multiple action & One action & Multiple action \\
\hline Age & 0.881 & 0.870 & -0.0948 & -0.134 \\
\hline Income & 1.040 & 1.142 & -0.0306 & 0.289 ** \\
\hline Education & 1.092 & $1.284^{* * *}$ & 0.0508 & 0.211 ** \\
\hline Male & 1.071 & 0.836 & -0.00677 & -0.165 \\
\hline Migrant & 1.225 & 1.694 ** & 0.0772 & 0.252 \\
\hline Attached refu & $1.465^{* * *}$ & $1.813^{* * *}$ & $0.399 * * *$ & $0.678 * * *$ \\
\hline Satgov_refu & $1.269^{* * *}$ & 1.093 & $0.243 * *$ & 0.104 \\
\hline Fair_refu & 1.199 & $1.792 * * *$ & 0.198 & $0.576 * * *$ \\
\hline Fair_mig & 1.152 & 0.993 & 0.114 & -0.0554 \\
\hline Refugeesupp & 1.107 & 1.118 & 0.129 & 0.140 \\
\hline Refugeemoral & 0.906 & 1.093 & -0.122 & -0.0733 \\
\hline Refugeecrisis & $1.370 * * *$ & 1.038 & $0.312 * * *$ & -0.00918 \\
\hline Syrian refugees & 0.860 & 0.812 & -0.0856 & -0.106 \\
\hline Inclusivity & 1.045 & 1.041 & 0.00293 & -0.0467 \\
\hline Socialclass & & & -0.147 & -0.0922 \\
\hline Reldep & & & -0.102 & $-0.224^{\star}$ \\
\hline Living in $\mathrm{DE}$ & & & 0.0296 & 0.0171 \\
\hline Friendsdiff & & & 0.00440 & $0.166^{*}$ \\
\hline Live alone & & & -0.241 & 0.272 \\
\hline East & & & -0.171 & -0.253 \\
\hline Attached DE & & & -0.144 & -0.193 \\
\hline Attached city & & & -0.116 & -0.140 \\
\hline Attached reg & & & 0.0994 & 0.0774 \\
\hline Attached EU & & & $0.300 * * *$ & -0.0525 \\
\hline Attached hu & & & $-0.276^{* *}$ & -0.165 \\
\hline Socialtrust & & & $0.223^{* *}$ & $0.191^{*}$ \\
\hline Religiosity & & & 0.202 ** & $0.536^{* * *}$ \\
\hline Identity & & & -0.146 & $-0.248 * *$ \\
\hline Lrscale & & & -0.00764 & $-0.246^{* *}$ \\
\hline Demsat & & & $-0.232^{* *}$ & 0.136 \\
\hline Multicultural & & & $0.226^{*}$ & 0.139 \\
\hline Populism & & & $0.144^{*}$ & $0.223^{* *}$ \\
\hline Xeno_econ & & & -0.0721 & 0.108 \\
\hline Xeno_culture & & & 0.122 & 0.185 \\
\hline Cons & $0.312 * * *$ & $0.143^{* * *}$ & $-0.983^{*}$ & $-1.287^{*}$ \\
\hline$N$ & 1236 & 1236 & 1236 & 1236 \\
\hline Pseudo- $R^{2}$ & 0.144 & 0.144 & 0.1870 & 0.1870 \\
\hline
\end{tabular}

${ }^{* * *} p<0.01,{ }^{* *} p<0.05,{ }^{*} p<0.1$ 
Table 3.8 Multinominal regression models for solidarity with unemployed people

\begin{tabular}{|c|c|c|c|c|}
\hline & \multicolumn{2}{|c|}{ Model 4e } & \multicolumn{2}{|c|}{ Model $5 e$} \\
\hline & One action & Multiple action & One action & Multiple action \\
\hline Age & $0.791 * * *$ & 0.887 & $-0.234 * * *$ & -0.148 \\
\hline Income & 1.102 & 1.074 & 0.0579 & 0.103 \\
\hline Education & 1.065 & $1.278 * * *$ & 0.0260 & $0.193^{*}$ \\
\hline Male & 1.191 & 1.327 & 0.115 & 0.293 \\
\hline Migrant & 0.937 & $1.507^{*}$ & -0.0770 & 0.252 \\
\hline Attached unemp & $1.666^{* * *}$ & $1.469 * * *$ & $0.483^{* * *}$ & 0.352 ** * \\
\hline Satgov_unemp & 1.042 & $0.739 * * *$ & 0.0836 & $-0.333^{* * *}$ \\
\hline Fairsocietey_jobs & 0.910 & 0.960 & -0.0806 & -0.00152 \\
\hline Inclusivityunemp & 1.020 & $1.255^{* *}$ & -0.0314 & 0.173 \\
\hline Socialclass & & & -0.0553 & -0.154 \\
\hline Reldep & & & -0.217 ** & $-0.382 * * *$ \\
\hline Living in DE & & & 0.117 & 0.0265 \\
\hline Friendsdiff & & & -0.0531 & -0.0257 \\
\hline Live alone & & & -0.429 ** & -0.167 \\
\hline East & & & 0.192 & -0.325 \\
\hline Attached DE & & & -0.131 & -0.199 \\
\hline Attached city & & & 0.0173 & -0.243 \\
\hline Attached reg & & & 0.163 & 0.101 \\
\hline Attached EU & & & $0.277^{* *}$ & $0.282 * *$ \\
\hline Attached hu & & & -0.0868 & -0.0236 \\
\hline Socialtrust & & & $0.278 * * *$ & -0.0257 \\
\hline Religiosity & & & $0.166^{* *}$ & $0.335 * * *$ \\
\hline Identity & & & -0.145 & 0.0213 \\
\hline Lrscale & & & -0.139 & 0.000612 \\
\hline Demsat & & & -0.144 & 0.0248 \\
\hline Multicultural & & & -0.172 & -0.0876 \\
\hline Populism & & & $0.268 * * *$ & 0.164 \\
\hline Xeno_econ & & & 0.0727 & 0.491 ** * \\
\hline Xeno_cult & & & 0.148 & -0.0832 \\
\hline Constant & $0.244 * * *$ & $0.119 * * *$ & -2.445 *** & $-2.361^{* * *}$ \\
\hline$N$ & 1261 & 1261 & 1261 & 1261 \\
\hline Pseudo- $R^{2}$ & 0.0503 & 0.0503 & 0.0958 & 0.0958 \\
\hline
\end{tabular}

${ }^{* * *} p<0.01,{ }^{* *} p<0.05,{ }^{*} p<0.1$

beliefs. Above the ideational-cultural items already included in previous analysis, in particular deprivation, social trust and religiosity, attachment to unemployed ( $M=2.93$, see Appendix) has a very clear impact on people choosing to act in solidarity as well as dissatisfaction with the government's policies on unemployment $(M=4.93)$. Solidarity activity on behalf 
of this group can thus be observed more likely when people identify with the unemployed and feel that they are treated unfairly (see also the positive effect of populism and deprivation). To some extent this explains the positive correlation of economic xenophobia, but not cultural xenophobia. The populism index we used includes statements like "Politicians in the parliament need to follow the will of the people" and "Political differences between the elite and the people are larger than among people" (see Appendix) and thus expresses discontent with the political system (not necessarily right-wing populism).

Finally, Table 3.9 summarizes the results of two models calculated to explain variance regarding solidarity actions on behalf of people with disabilities. Education stays a relevant factor in explaining solidarity actions on behalf of disabled. Beyond the already reported variables, we find again the feeling of attachment to the specific group ( $M=3.40$, see Appendix) to be important in explaining solidarity activity. The belief, a fair society should include people with disabilities $(M=4.24)$, is relevant for people active in multiple ways. Overall and in comparison to the other issue fields investigated so far, we confirm that solidarity with disabled people is less contentious. For example, only $2.4 \%$ of respondents saw it as "not at all" or "not very" important that people with disabilities are included in public life. Similarly, the attachment (reported mean) is higher than with refugees and the unemployed. Thus, in comparison, questions on refugees and their rights were answered more diversely. Also in regards to correlating variables, solidarity with disabled is closer to solidarity with unemployed than to solidarity with refugees.

\section{Conclusion}

Our investigation set out to describe the frequency of solidarity activities in Germany, investigate socio-economic and cultural-ideational determinants and, last but not least, test for issue-specific motifs and political beliefs. First, we compared the relative frequencies of solidarity activities. We found solidarity to depend on geographic proximity, as the way and frequency of people engaging varies across spatial levels, and also to depend on issue fields: solidarity activity with disabled people is more common than activism on behalf of other groups, and, at the moment, the needs of refugees are addressed more often than those of the unemployed through these type of political actions. This suggests that solidarity at the individual level is not universalistic but rather particularistic. 
Table 3.9 Multinominal regression models for solidarity with people with disabilities

\begin{tabular}{|c|c|c|c|c|}
\hline & \multicolumn{2}{|c|}{ Model $4 f$} & \multicolumn{2}{|c|}{ Model $5 f$} \\
\hline & One action & Multiple action & One action & Multiple action \\
\hline Age & 0.901 & 0.935 & -0.0947 & -0.0608 \\
\hline Income_D & $1.137^{*}$ & 1.103 & 0.129 & -0.00681 \\
\hline Education & 1.026 & $1.377 * * *$ & 0.00221 & $0.297 * * *$ \\
\hline Male & 0.974 & 0.975 & -0.0447 & -0.0159 \\
\hline Migrant & 0.940 & 1.127 & -0.154 & -0.142 \\
\hline Attached disab & $1.525 * * *$ & $1.848 * * *$ & 0.430 ** * & 0.710 ** * \\
\hline Satgov disab & 1.098 & 0.906 & 0.0363 & -0.139 \\
\hline Fairsocietey_disa & 1.021 & 1.191 * & 0.0298 & $0.189^{*}$ \\
\hline Inclusivity disab & 1.028 & 1.091 & 0.0111 & 0.0636 \\
\hline Socialclass & & & -0.00779 & $-0.197^{*}$ \\
\hline Reldep & & & $-0.156^{*}$ & -0.178 \\
\hline Living in DE & & & 0.0242 & -0.00897 \\
\hline Friendsdiff & & & 0.00641 & 0.0925 \\
\hline Live alone & & & -0.166 & $-0.391^{*}$ \\
\hline East & & & 0.0872 & -0.218 \\
\hline Attached DE & & & 0.0408 & -0.0577 \\
\hline Attached city & & & $-0.274^{* *}$ & -0.134 \\
\hline Attached reg & & & $0.188^{*}$ & 0.00900 \\
\hline Attached EU & & & $0.188^{*}$ & 0.0799 \\
\hline Attached hu & & & 0.103 & 0.178 \\
\hline Socialtrust & & & $0.240^{* * *}$ & 0.107 \\
\hline Religiosity & & & 0.190 ** & $0.385 * * *$ \\
\hline Identity & & & -0.133 & $-0.258 * *$ \\
\hline Lrscale & & & 0.0781 & -0.00382 \\
\hline Demsat & & & -0.00601 & 0.0909 \\
\hline Multicultural & & & 0.104 & 0.0866 \\
\hline Populism & & & 0.159 ** & $0.194^{* *}$ \\
\hline Xeno_econ & & & 0.0331 & 0.250 ** \\
\hline Xeno_cult & & & -0.0557 & -0.0869 \\
\hline Constant & 0.879 & $0.438 * * *$ & -0.577 & $-1.034^{*}$ \\
\hline Observations & 1235 & 1235 & 1235 & 1235 \\
\hline Pseudo- $R^{2}$ & 0.0458 & 0.0458 & 0.0838 & 0.0838 \\
\hline
\end{tabular}

${ }^{* * *} p<0.01,{ }^{* *} p<0.05,{ }^{*} p<0.1$

Moreover, our results indicate that solidarity depends not only on spatial proximity but also on social proximity.

Second, while we did not find clear socio-economic patterns that held across levels and issue fields, it seems as if the not-engaged are of diverse 
age, the one-action activists across levels and issues are often of younger age and the multiple activists are older. In addition, higher education seems to increase solidarity activity at least in some respects. Furthermore, across issue fields, higher social trust and religiosity seem to provide people with the motivation and (ideational) resources to engage on the behalf of others. Beyond that, our findings point to issue-specific explanations. For example, we found relative deprivation to increase the support of unemployed people and higher attachment with Europe as well as lower attachment with Germany to increase solidarity with people in other European countries.

Thus, in the third step, we sought to confirm this interpretation by including extra variables for models designed specifically for each specific issue fields, namely, support of other people in Europe, refugees, unemployed and people with disabilities. We confirmed that indeed attachment to specific groups also increased solidarity activity on behalf of them. In this respect, our findings corroborate the idea that solidarity is not a universalist inclination directed to any human being regardless of his or her affiliation or background. Instead, acting in solidarity is rather linked to specific groups to which one feels particularly close or attached. Moreover, attachment to different groups differs: it is highest towards disabled people and lowest, comparing our three issue fields, towards refugees (see means in Appendix). In this respect, feelings of social proximity to and empathy with certain target groups are important prerequisites for solidarity engagement in support of others.

Furthermore, satisfaction with government policies on specific issues might increase or decrease solidarity. For unemployment, people who are dissatisfied with the government are more likely to help those who are unemployed. This further supports our observation that social proximity and empathy help to mobilize support of particular groups because we can assume that people who express discontent with the government's unemployment policies have directly or indirectly (by observation) experienced the impact of these policies themselves and can thus identify with the situation of the unemployed. As for the issue of refugee policies, we observe the opposite relationship. Those who feel empathy with refugees would tend to be those who agree with the German "welcome policy" and also to be the type of individuals who would engage in actions to help refugees. In summary, our analysis has shown how, at least for the case of Germany, across the issue fields that social proximity and empathy with certain groups encourage solidarity behaviours. 


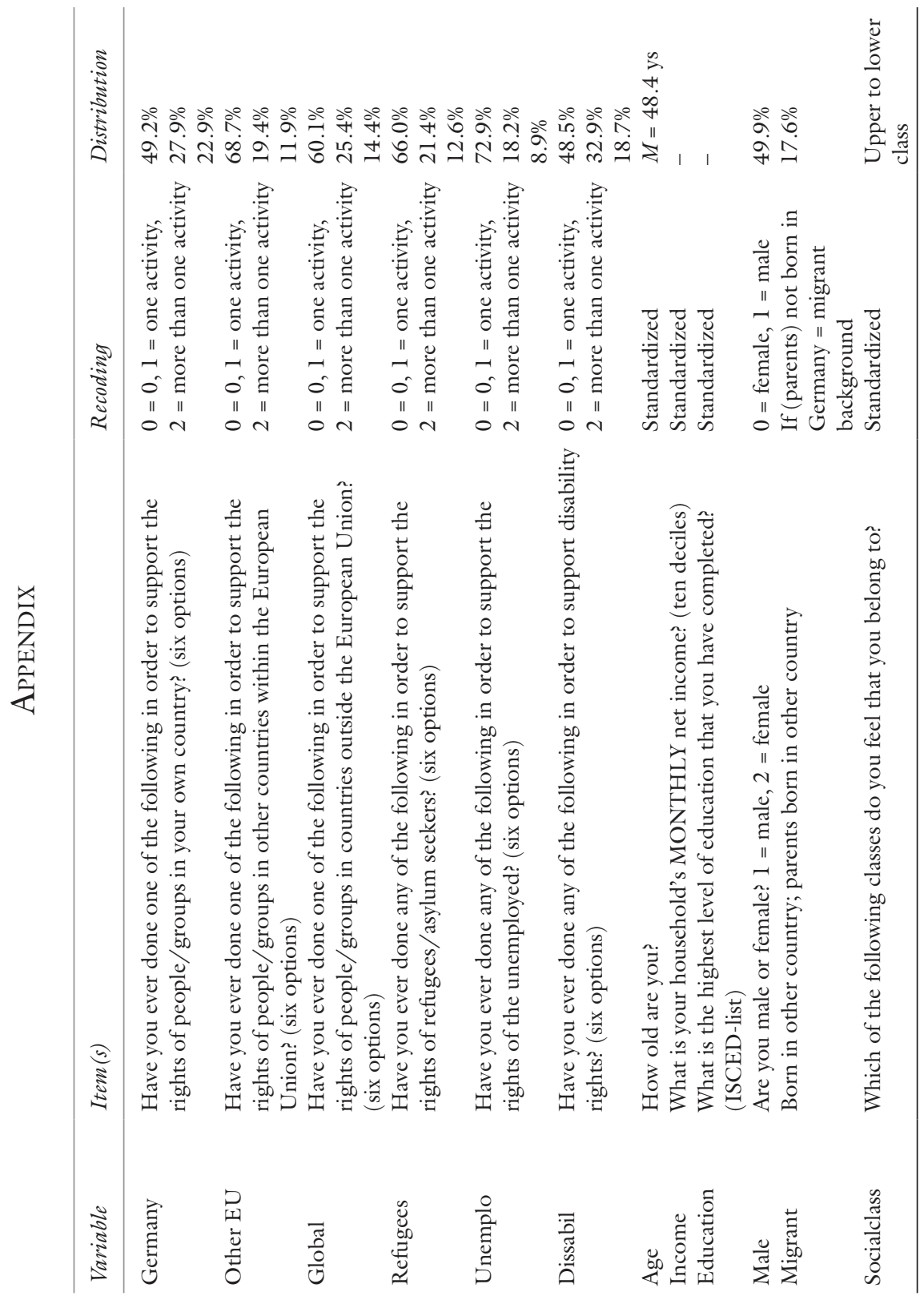




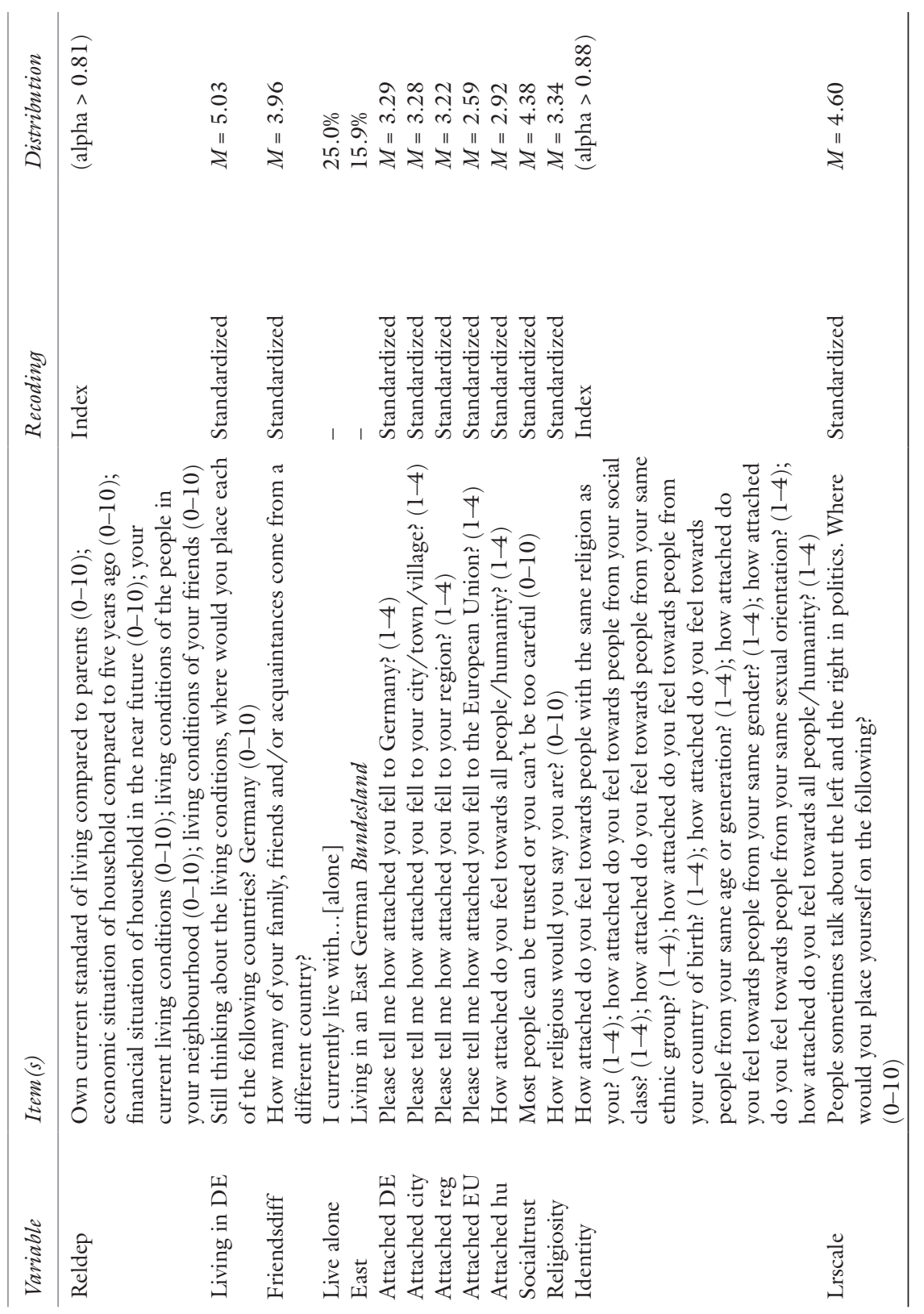




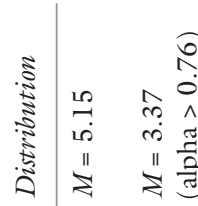

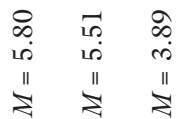

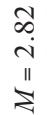

ஸें i⿱
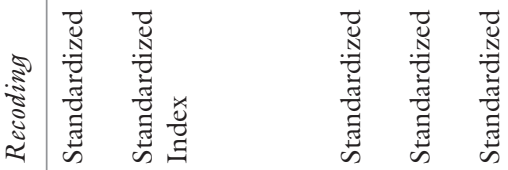

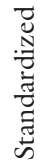

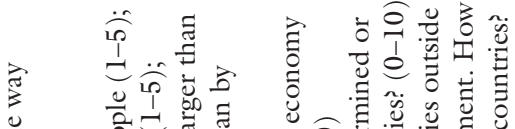

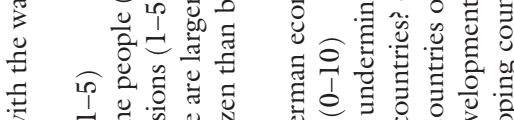

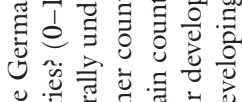

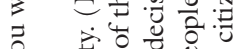

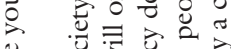

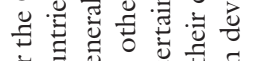

䒕

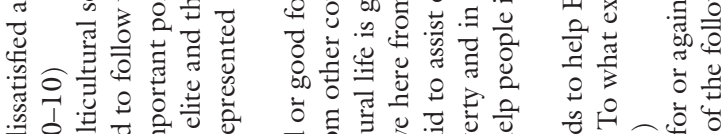

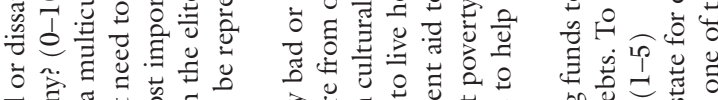

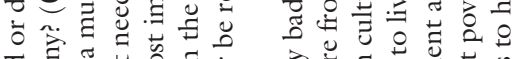

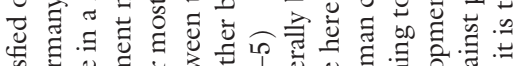

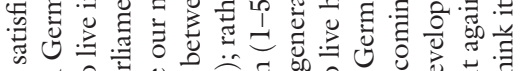

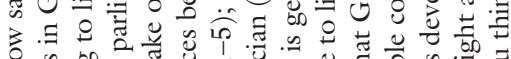

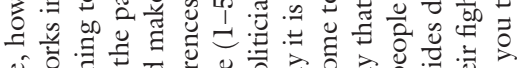

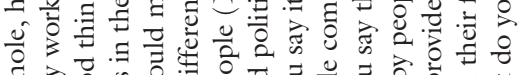

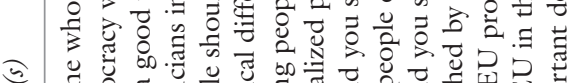

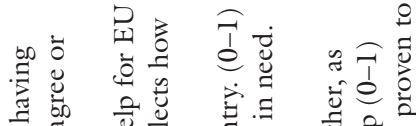

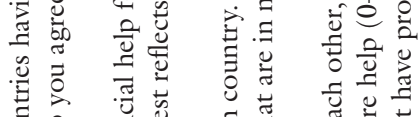

节它 㻤

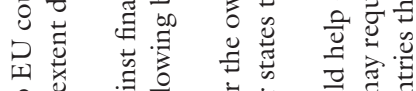

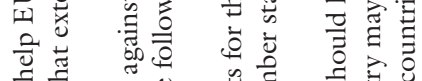

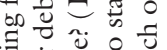

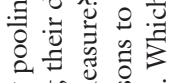

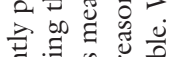

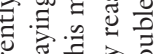

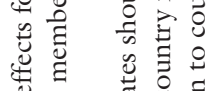

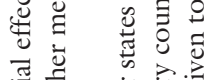

氶苛

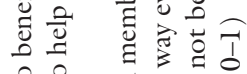

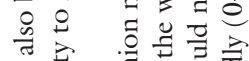
党至 可志

을 중

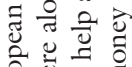
$\because \mathscr{0}$

केष

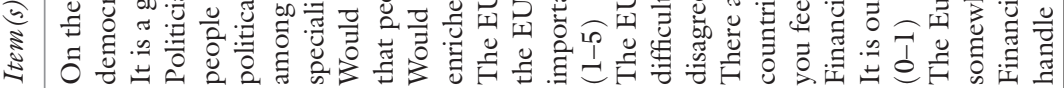

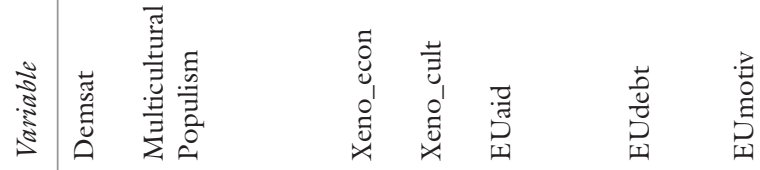




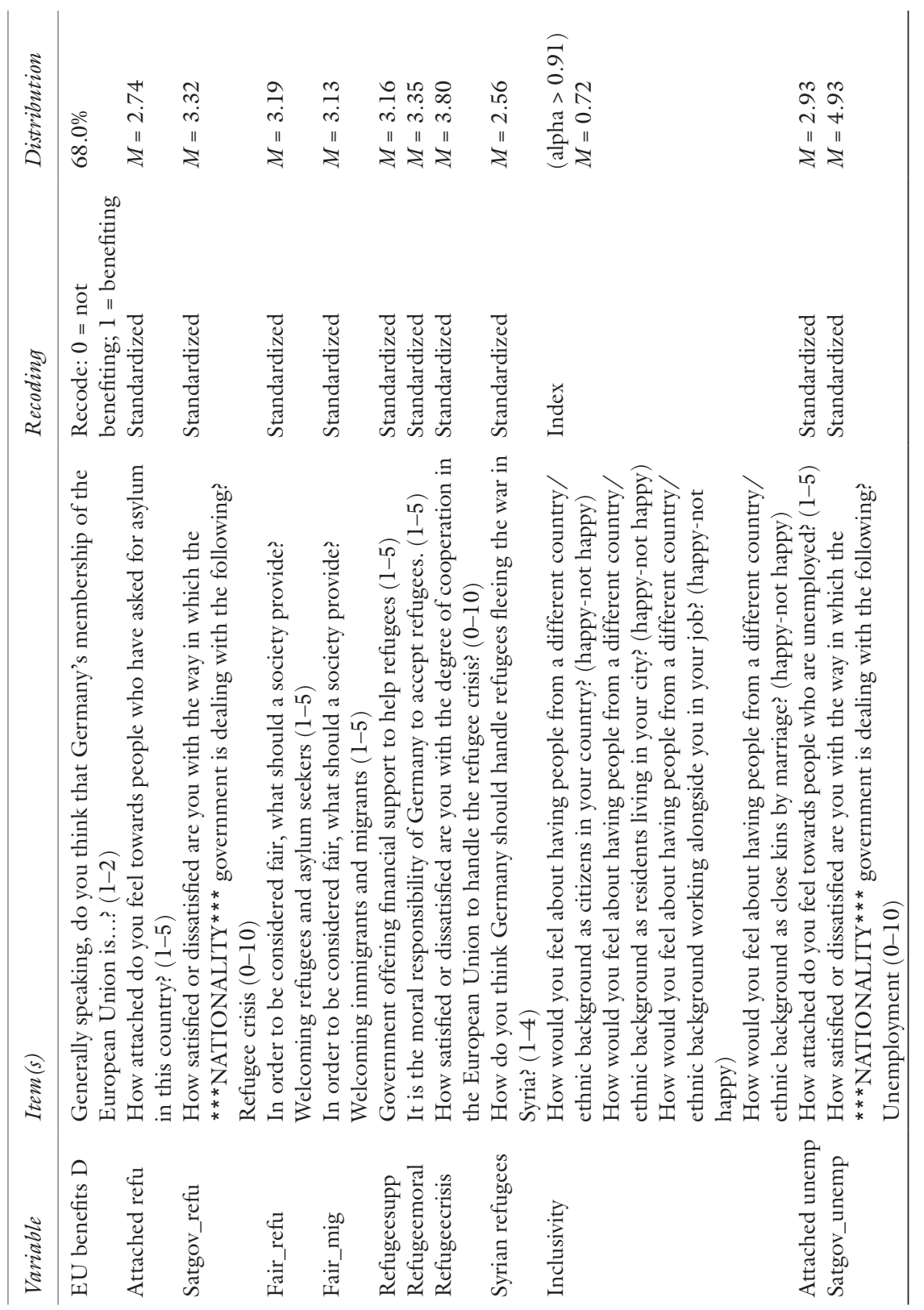



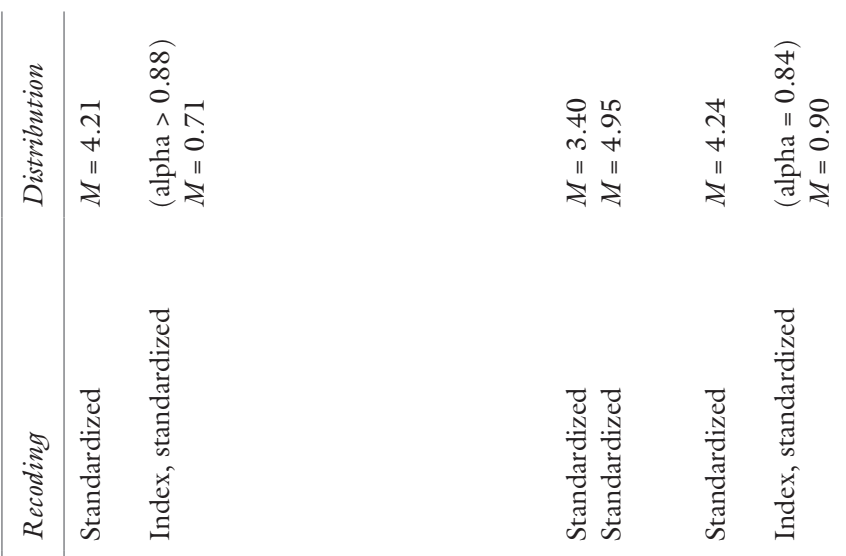

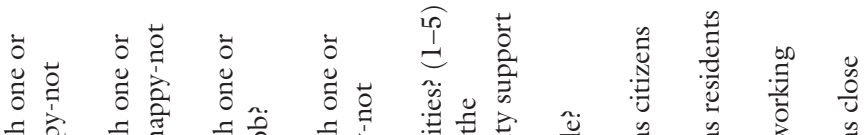

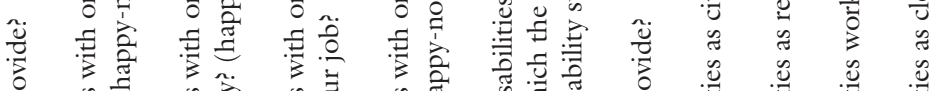

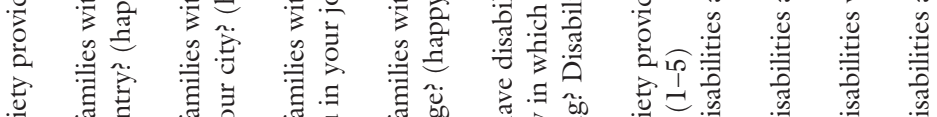

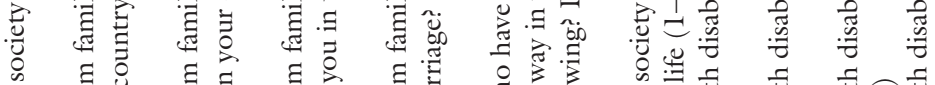

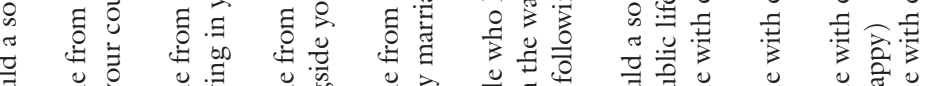

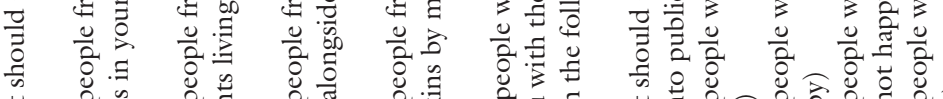

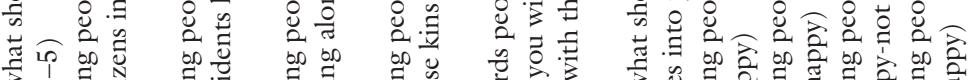

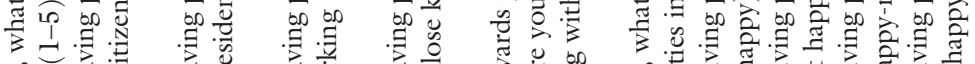

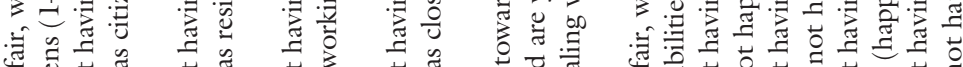

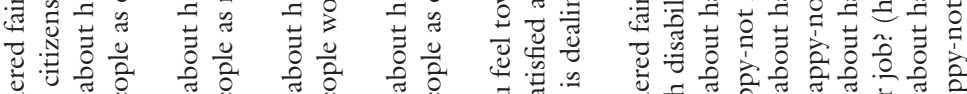

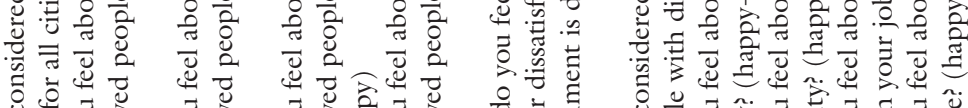

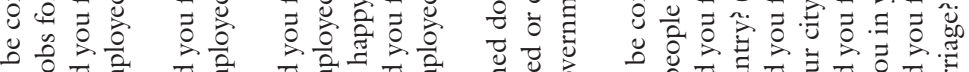

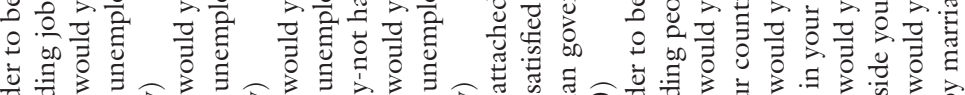

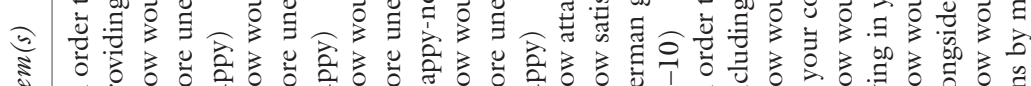

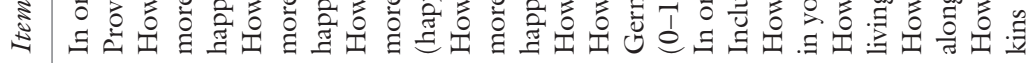

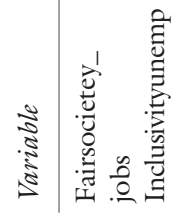

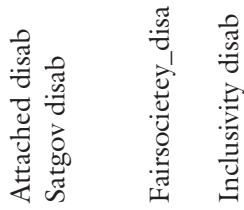




\section{Notes}

1. Further information is available at the project website www.transsol.eu.

2. The results were very clear for all analyses conducted. Still, in addition to the principal factor analysis, we also conducted principal component analyses as well as iterated principal factor analyses but did not find any hints for another factor.

3. Nota bene: we did not ask people how often they engaged in the activities. We instead combine the different activities, arguing that engaging in multiple activities equals higher solidarity. This does not mean that one cannot be involved deeply in one activity expressing solidarity in this way. We account for this in the following analyses by including the one-action activists as an extra group.

4. Regressions for single items did not produce clearer patterns.

5. A lower score marks lower self-placement (and thus higher deprivation); a higher score means people feel better off.

6. Since solidarity actions on behalf of people in Germany and on behalf of people in non-European countries are more difficult to isolate, we exclude them from the following analysis.

\section{REFERENCES}

Bauböck, R. (2017). Citizenship and Collective Identities as Political Sources of Solidarity in the European Union. In K. Banting \& W. Kymlicka (Eds.), The Strains of Commitment. The Political Sources of Solidarity in Diverse Societies (pp. 80-106). Oxford: Oxford University Press.

Beyerlein, K., \& Bergstrand, K. (2013). Biographical Availability. In D. A. Snow, D. della Porta, B. Klandermans, \& D. McAdam (Eds.), The Wiley-Blackwell Encyclopedia of Social and Political Movements (pp. 137-138). New York: Wiley-Blackwell.

Brady, H. E., Verba, S., \& Schlozman, K. L. (1995). Beyond SES: A Resource Model of Political Participation. The America Political Science Review, 89(2), 271-294.

Cainzos, M., \& Voces, C. (2010). Class Inequalities in Political Participation and the 'Death of Class' Debate. International Sociology, 25(3), 383-418.

Eder, K. (1993). The New Politics of Class: Social Movements and Cultural Dynamics in Advanced Societies. London: Sage Publications.

Edwards, B., \& McCarthy, J. D. (2004). Resources and Social Movement Mobilization. In D. A. Snow, S. A. Soule, \& H. Kriesi (Eds.), The Blackwell Companion to Social Movements (pp. 116-152). Oxford: Blackwell.

Iversen, T., \& Soskice, D. (2001). An Asset Theory of Social Policy Preferences. American Political Science Review, 95(4), 875-893. 
Jenkins, J. C. (1983). Resource Mobilization Theory and the Study of Social Movements. Annual Review of Sociology, 9, 527-553.

Komter, A. E. (2005). Social Solidarity and the Gift. Cambridge: Cambridge University Press.

Kriesi, H. (1989). New Social Movements and the New Class in the Netherlands. American Journal of Sociology, 94(5), 1078-1116.

Kronauer, M. (1998). 'Social Exclusion' and 'Underclass': New Concepts for the Analysis of Poverty. In A. Hans-Jürgen (Ed.), Empirical Poverty Research in a Comparative Perspective (pp. 51-75). Aldershot: Ashgate.

Lichterman, P. (2015). Religion and Social Solidarity. A Pragmatist Approach. In L. Hustinx, J. von Essen, J. Haers, \& S. Mels (Eds.), Religion and Volunteering. Complex, Contested and Ambiguous Relationships (pp. 241-261). Cham: Springer.

Likki, T., \& Staerklé, C. (2014). A Typology of Ideological Attitudes Towards Social Solidarity and Social Control. Journal of Community and Applied Social Psychology, 24, 406-421.

Morokvasic, M. (1999). La mobilité transnationale comme ressource: le cas des migrants de l'Europe de l'Est. Cultures et Conflits, 32, 105-122.

Putnam, R., Feldstein, L. M., \& Cohen, D. (2003). Better Together: Restoring the American Community. New York: Simon \& Schuster.

Rehm, P. (2009). Risks and Redistribution. An Individual-Level Analysis. Comparative Political Studies, 42(7), 885-881.

Schiffauer, W., Eilert, A., \& Rudloff, M. (Eds.). (2017). So schaffen wir das-eine Zivilgesellschaft im Aufbruch: 90 wegweisende Projekte mit Geflüchteten. Bielefeld: transcript.

Schulze, R. (2004). Islamische Solidaritätsnetzwerke: Auswege aus den verlorenen Versprechen des modernen Staates. In J. Beckert, J. Eckert, M. Kohli, \& W. Streeck (Eds.), Transnationale Solidarität. Chancen und Grenzen (pp. 195-219). Frankfurt a. M: Campus.

Stegmueller, D., Scheepers, P., Roßteuscher, S., \& de Jong, E. (2012). Support for Redistribution in Western Europe. Assessing the Role of Religion. European Sociological Review, 28(4), 482-497.

van Oorschot, W. (2006). Making the Difference in Social Europe: Deservingness Perceptions Among Citizens of European Welfare States. Journal of European Social Policy, 16(1), 23-42.

van Oorschot, W., Arts, W., \& Gelissen, J. (2006). Social Capital in Europe. Measurement and Social and Regional Distribution of a Multifaceted Phenomenon. Acta Sociologica, XLIX, 149-167.

Verba, S., Nie, N., \& Kim, J. (1978). Participation and Political Equality: A Seven Nation Comparison. London: Cambridge University Press.

Verba, S., Schlozman, K. L., \& Brady, H. E. (1995). Voice and Equality: Civic Voluntarism in American Politics. Cambridge: Harvard University Press. 
Open Access This chapter is licensed under the terms of the Creative Commons Attribution 4.0 International License (http://creativecommons.org/licenses/ by $/ 4.0 /$ ), which permits use, sharing, adaptation, distribution and reproduction in any medium or format, as long as you give appropriate credit to the original author(s) and the source, provide a link to the Creative Commons license and indicate if changes were made.

The images or other third party material in this chapter are included in the chapter's Creative Commons license, unless indicated otherwise in a credit line to the material. If material is not included in the chapter's Creative Commons license and your intended use is not permitted by statutory regulation or exceeds the permitted use, you will need to obtain permission directly from the copyright holder.

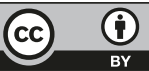

